\title{
Retinal circulation times in diabetes mellitus type 1
}

\author{
Bernd Bertram, Sebastian Wolf, Susanne Fiehöfer, Karin Schulte, Oliver Arend, Martin Reim
}

\begin{abstract}
Video fluorescein angiography was performed in 124 patients between 18 and 65 years of age (mean 35.0, SD 12.3 years) with juvenileonset, insulin-dependent diabetes mellitus (type 1). The arm-retina time (ART) and the retinal arteriovenous passage time (AVP) were measured by means of a picture analysis system to quantify the retinal microcirculation. Glucose metabolism was assessed by the blood level of haemoglobin A1c. The ART 11.5 , SD $3.4 \mathrm{~s})$ was similar to that in normal persons (11.2, SD 3.3 s), while the AVP was significantly longer in the diabetics $(A V P=2 \cdot 35$, SD 0.87 s) than in normal persons $(A V P=1.45$, SD $0.40 \mathrm{~s}$ ). The patients with severe diabetic retinopathy showed the most impressive change in AVP. The diabetics with good glycaemic control, that is, with glycosylated haemoglobin $(\mathrm{HbAlc}) \leqslant 8.0 \mathrm{~g} / \mathrm{dl}$, had a shorter AVP than patients with bad glycaemic control (HbAlc $\geqslant 9.5 \mathrm{~g} / \mathrm{dl}$ ). The group with a history of diabetes for less than five years showed circulation parameters similar to those of normal persons. The AVP in this group was significantly shorter than in groups with a history of diabetes for five or more years.
\end{abstract}

Most patients with diabetes mellitus develop characteristic abnormalities of the retinal blood vessels and the blood rheology. These abnormalities seem to alter the retinal blood flow in diabetic persons.

Video fluorescein angiography, combined with a picture analysing system, is a clinically applicable objective method for evaluating retinal circulation parameters.' Until August 1989 the system included a low light videocamera (Bosch) and a fundus camera (C Zeiss). Thereafter both devices were replaced by a scanning-laser-ophthalmoscope (SLO, Rodenstock). This new SLO gave similar results. ${ }^{2}$ The measuring technique used has been presented in detail elsewhere. ${ }^{1}$ The present paper reports the measurement of retinal circulation in juvenileonset insulin dependent diabetic persons (type 1) by means of video fluorescein angiography.

Augenklinik der RWTH Aachen, Pauwelsstrasse 30, 5100 Aachen, Germany B Bertram $S$ Wolf S Fiehöfer K Schulte O Arend M Reim

Correspondence to: Dr B Bertram.

Accepted for publication 21 December 1990

\section{Materials and methods}

We studied 124 patients with juvenile-onset insulin dependent diabetes mellitus (type 1) (71 male, 53 female) aged between 18 and 65 years (mean 35.0 SD, 12.3 years). The history of diagnosed diabetes ranged between 0.1 and $51 \cdot 4$ years (mean 18.5 , SD 10.3 years). Twenty one patients $(16.9 \%)$ had a history of systemic hypertension. No other retinal or systemic disease was found in any patient. The results obtained from diabetics were compared with those of an agematched control group of apparently healthy
Table 1 Characteristics of juvenile-onset diabetics and normal subjects

\begin{tabular}{lll}
\hline & $\begin{array}{l}\text { Diabetics } \\
(n=124)\end{array}$ & $\begin{array}{l}\text { Normal } \\
(n=75)\end{array}$ \\
\hline Sex M/F & $71 / 53$ & $30 / 45$ \\
Age (yr) & $35(12)$ & $32(13)$ \\
Duration of diabetes (yr) & $18(10)$ & - \\
HbAlc (g/dl) & $8 \cdot 8(1 \cdot 9)$ & - \\
Systolic blood pressure (mmHg) & $135(25)$ & $134(13)$ \\
Diastolic blood pressure (mmHg) & $81(12)$ & $77(9)$ \\
History of hypertension (\%) & 16.9 & - \\
\hline
\end{tabular}

SD in parentheses.

volunteers. The characteristics of the diabetic and the normal subjects are summarised in Table 1. No significant difference between the groups was found with respect to age and systolic and diastolic blood pressure.

The severity of diabetic retinopathy was evaluated by ophthalmoscopy, fundus photography, and angiography. The diabetic patients were distributed into four groups: (1) no retinopathy (DR 0); (2) mild to moderate non-proliferative retinopathy (that is, microaneurysms, haemorrhages, hard exudates) (DR 1); (3) preproliferative retinopathy (that is, multiple cotton-wool spots, intraretinal microvascular abnormalities, venous beading, or areas of nonperfusion) (DR 2); (4) proliferative retinopathy (DR 3).

Glucose metabolism was assessed by the blood level of glycosylated haemoglobin (HbAlc) (normal range: $4 \cdot 3-6 \cdot 0 \mathrm{~g} / \mathrm{dl}$ ). ${ }^{3}$

We found a significant difference in age and duration of diabetes $(a)$ between diabetics with no retinopathy (DR 0 ) and the other groups $(p<0.01)$ and $(b)$ between diabetics with mild to moderate non-proliferative retinopathy (DR 1) and proliferative retinopathy (DR 3$)(\mathrm{p}<0.05)$. There was no significant difference between the groups regarding sex and glycaemic control (HbAlc). A significantly increased systolic and diastolic blood pressure was found in patients with proliferative retinopathy (DR 3) as compared with the other groups.

Video fluorescein angiography was performed on all subjects. The circulation parameters armretina time (ART) and retinal arteriovenous passage time (AVP) were measured by means of a picture analysing system.' The ART consists of the period of time between the injection of dye
Table 2 Circulation parameters of juvenile-onset diabetic and normal subjects

\begin{tabular}{|c|c|c|c|}
\hline & No & $\begin{array}{l}\text { Arm-retina } \\
\text { time }(s)\end{array}$ & $\begin{array}{l}\text { Arteriovenous passage } \\
\text { time }(s)\end{array}$ \\
\hline $\begin{array}{l}\text { Diabetic patients } \\
\text { Normal subjects } \\
\text { Significance }\end{array}$ & $\begin{array}{r}124 \\
75\end{array}$ & $\begin{array}{l}11 \cdot 5(3 \cdot 4) \\
11 \cdot 2(3 \cdot 3) \\
\text { NS }\end{array}$ & $\begin{array}{l}2.35(0.87) \\
1.45(0.40) \\
p<0.01\end{array}$ \\
\hline
\end{tabular}

$\mathrm{SD}$ in parentheses. 
the retinal arteries. It allows a rough estimation of the macrocirculation. The AVP is defined as the interval between the first influx of dye into a retinal artery and its first appearance in the corresponding retinal vein. It is the time the indicator requires for passing through a corresponding area of retinal microcirculation.

\section{STATISTICS}

Mean value and standard deviation are given for all samples. To assess the significance of the results non-parametric tests (Mann-Whitney U test; Kruskal-Wallis test) were used. For multiple group test statistics the Kruskal-Wallis test with subsequent Holm's sequential rejective multiple test procedure ${ }^{4}$ was applied. Findings with an error probability value smaller than 0.05 were considered to be statistically significant.

\section{Results}

Table 2 shows the circulation parameters of juvenile-onset diabetic and normal subjects. The arm-retina time was similar in both groups. A significant prolongation of the AVP in diabetics was found.

The influence of the stage of diabetic retinopathy on the circulation parameters is shown in Table 3. No significant difference of arm-retina time was found between the groups. The AVP was significantly prolonged in all four groups as compared with the normal subjects. There was an increase of AVP with progressing diabetic retinopathy. The differences in AVP between RD 0 and RD $1(\mathrm{p}<0.05), \mathrm{RD} 0$ and RD 2 $(\mathrm{p}<0.05)$, RD 0 and RD 3 ( $\mathrm{p}<0.01)$, and RD 1 and RD $3(p<0.01)$ were significant. HbAlc was unchanged throughout the various stages of diabetic retinopathy.

To determine the influence of glycaemic control on the circulation parameters groups with good (HbAlc $\leqslant 8.0 \mathrm{~g} / \mathrm{dl}$ ) and bad glycemic control (HbAlc $\geqslant 9.5 \mathrm{~g} / \mathrm{dl}$ ) were compiled. Patients with an HbAlc concentration between 8.1 and $9.4 \mathrm{~g} / \mathrm{dl}$ were not included. There was no significant difference in the arm-retina time between the two groups. The diabetics with bad glycaemic control showed a significant increase of AVP as compared with patients with good glycaemic control (Table 4).

Table 5 shows the AVP of juvenile-onset diabetics with good and bad glycaemic control and stage of diabetic retinopathy. Diabetics without any sign of retinopathy (DR 0 ) and with good glycaemic control showed an AVP similar to that of healthy individuals. In mild to moderate non-proliferative retinopathy (DR 1) and in preproliferative retinopathy (DR 2) the AVP was significantly $(p<0.01)$ longer in patients with bad glycaemic control than in diabetics with good glycaemic control. The AVP of diabetics with proliferative retinopathy (DR 3) seemed to be independent of glycaemic control.

The influence of the duration of diabetes on the circulation parameters is shown in Table 6 . The group with a history of diabetes $<5$ years had a normal ART and AVP as compared with healthy persons. Six of nine diabetics with duration of diabetes $<5$ years had a value of
Table 3 Circulation parameters of juvenile-onset diabetics and stage of diabetic retinopathy $(D R)$ (DRO: no retinopathy; DR 1: mild to moderate non-proliferative retinopathy; DR2: preproliferative retinopathy; DR3: proliferative retinopathy)

\begin{tabular}{llll}
\hline Stage of DR & No. & $\begin{array}{l}\text { Arm-retina } \\
\text { time }(s)\end{array}$ & $\begin{array}{l}\text { Arteriovenous passage } \\
\text { time }(s)\end{array}$ \\
\hline DR 0 & 27 & $11.5(3.5)$ & $1.84(0.67)$ \\
DR 1 & 39 & $11 \cdot 1(2.8)$ & $2.28(0.78)$ \\
DR 2 & 22 & $11.1(3.1)$ & $2.44(0.88)$ \\
DR 3 & 36 & $112.2(4.2)$ & $2.75(0.91)$ \\
Significance & & NS & p<0.01 \\
\hline
\end{tabular}

SD in parentheses.

Table 4 Arm-retina time (ART) and arteriovenous passage time (AVP) of juvenile-onset diabetics with good (HbAlc $\leqslant 8.0 \mathrm{~g} / \mathrm{dl}$ ) and bad glycaemic control ( $\mathrm{HbA} / \mathrm{c} \geqslant 9.5 \mathrm{~g} / \mathrm{dl})$

\begin{tabular}{|c|c|c|c|}
\hline No. & $A R T(s)$ & $A V P(s)$ & $H b A l c(g / d l)$ \\
\hline $\begin{array}{l}\text { Good glycaemic control } 35 \\
\text { Bad glycaemic control } 34 \\
\text { Significance }\end{array}$ & $\begin{array}{l}11 \cdot 4(3 \cdot 2) \\
11 \cdot 1(2 \cdot 9) \\
\text { NS }\end{array}$ & $\begin{array}{l}1.90(0.67) \\
2.62(0.86) \\
p<0.01\end{array}$ & $\begin{array}{l}7.0(0.8) \\
10 \cdot 8(1 \cdot 3) \\
p<0.01\end{array}$ \\
\hline
\end{tabular}

SD in parentheses.

Table 5 Arteriovenous passage time (AVP) of juvenile-onset diabetics with good $(\mathrm{HbAlc} \leqslant 8.0 \mathrm{~g} / \mathrm{dl})$ and bad glycaemic control (HbAlc $\geqslant 9.5 \mathrm{~g} / \mathrm{dl})$ and stage of diabetic retinopathy (DR) (DRO: no retinopathy; DRI: mild to moderate nonproliferative retinopathy; DR2: preproliferative retinopathy; DR 3: proliferative retinopathy $)\left({ }^{\star}=p<0.01\right.$ between good and bad control)

\begin{tabular}{lll}
\hline Stage of DR & $\begin{array}{l}\text { Good glycaemic control } \\
A V P(s)\end{array}$ & $\begin{array}{l}\text { Bad glycaemic control } \\
A V P(s)\end{array}$ \\
\hline DR 0 & $1 \cdot 40(0 \cdot 59): \mathrm{n}=8$ & $1 \cdot 98(0 \cdot 51): \mathrm{n}=5$ \\
DR 1 & $1 \cdot 86(0 \cdot 40): \mathrm{n}=12$ & $2 \cdot 51\left(0 \cdot 36^{\star}\right): \mathrm{n}=10$ \\
DR 2 & $1 \cdot 84(0 \cdot 44): \mathrm{n}=9$ & $3 \cdot 00\left(1 \cdot 03^{\star}\right): \mathrm{n}=8$ \\
DR 3 & $2 \cdot 71(0 \cdot 85): \mathrm{n}=6$ & $2 \cdot 82(1 \cdot 05): \mathrm{n}=11$ \\
\hline
\end{tabular}

$\mathrm{SD}$ in parentheses.

Table 6 Circulation parameters of juvenile-onset diabetics and duration of diagnosed diabetes

\begin{tabular}{lcll}
\hline $\begin{array}{l}\text { Duration } \\
\text { of diabetes }(y r)\end{array}$ & No. & $\begin{array}{l}\text { Arm-retina } \\
\text { time }(s)\end{array}$ & $\begin{array}{l}\text { Arteriovenous passage } \\
\text { time }(s)\end{array}$ \\
\hline$<5$ & 9 & $11 \cdot 4(2 \cdot 1)$ & $1 \cdot 56(0 \cdot 48)$ \\
$5-14$ & 40 & $11 \cdot 1(3 \cdot 6)$ & $2 \cdot 24(0 \cdot 87)$ \\
$15-24$ & 48 & $11 \cdot 0(2 \cdot 9)$ & $2 \cdot 52(0 \cdot 94)$ \\
$\geqslant 25$ & 27 & $13 \cdot 0(4 \cdot 1)$ & $2 \cdot 47(0 \cdot 69)$ \\
\hline
\end{tabular}

$\mathrm{SD}$ in parentheses.

HbAlc $\leqslant 7 \cdot 5 \mathrm{~g} / \mathrm{dl}$. The AVP in this group is significantly shorter than in the other three groups with duration of diabetes $\geqslant 5$ years $(p<0.01)$. No significant change of AVP was found among the other groups (duration of diabetes: $5-14,15-24$, and $\geqslant 25$ years). The ART of the three groups $<25$ years was similar to the ART of healthy persons. Only the group with duration of diabetes $\geqslant 25$ years showed an increased arm-retina time $(\mathrm{p}<0.05)$ as compared with healthy persons and with diabetics with a history of diabetes for 5-14 and 15-24 years.

\section{Discussion}

The initial lesions of diabetic retinopathy affect capillaries, small arterioles, and venules. The earliest changes are retinal capillary bed obstructions and capillary dropout. ${ }^{5}$ Progressive thickening of the basement membrane narrows the lumen of capillaries; microaneurysms, venous abnormalities, arteriovenous shunts, and later neovascularisation develop. These changes of vessel morphology may disturb the retinal microcirculation. 
Furthermore, diabetes mellitus affects the blood rheology. Increasing blood viscosity and plasma viscosity, ${ }^{6-8}$ increasing red blood cell aggregation, ${ }^{8-10}$ and increasing platelet aggregation and change of platelet shape ${ }^{1112}$ reduce the retinal blood flow, if not compensated by regulatory means.

The AVP is the shortest time of fluorescein circulating through a corresponding area of retinal microcirculation. We found an increased AVP in adult type 1 diabetics. This indicates a disturbed microcirculation. Previous work had suggested that retinal blood flow would be increased in prediabetes ${ }^{13}$ and in some stages of diabetic retinopathy. ${ }^{14-16}$ However, our finding of increased AVP is in agreement with other investigations of decreased retinal blood flow or increased retinal circulation times using the blue light entoptic phenomenon, ${ }^{17} 18$ laser Doppler velocimetry, ${ }^{19}$ photoangiography, ${ }^{2021}$ or twopoint fluorophotometry. ${ }^{22}$ With video fluorescein angiography we found prolonged AVP in type 2 diabetics. ${ }^{23}{ }^{24}$ These methods of measuring retinal circulation evaluate different parts of the retinal circulation. The blue light entoptic phenomenon ${ }^{1725}$ allows determination of the perifoveal flow velocity of leucocytes; laser Doppler velocimetry measures the velocity of red blood cells. ${ }^{19}$ Two-point fluorophotometry $^{1516}$ measures blood flow velocities in the major retinal vessels; two-point fluorophotometry, ${ }_{,}^{22}$ photoangiography, ${ }^{2021}$ and with more precision video fluorescein angiography measure the time interval of fluorescein from arteriole to the corresponding venule. In capillaries of the conjunctiva bulbi ${ }^{2627}$ and of the nailfold ${ }^{28} a$ decreased blood velocity was also found in diabetics. The prolonged AVP may be due to the morphological changes of the retinal vessels and to the disturbed blood rheology in diabetes mellitus.

By means of photoangiography Ferrer ${ }^{20}$ found retinal circulation times of four long-standing diabetics without retinopathy to be similar to that of normal persons. Two cases of longstanding diabets with retinopathy were found to have a delayed circulation. Kohner et al. ${ }^{14}$ showed that the mean transit time is decreased in no or mild diabetic retinopathy and bears normal values in moderate and in severe retinopathy. Cunha-Vaz et al..$^{15}$ found an increase of retinal blood flow in minimal and more advanced stages of background retinopathy and decreasing retinal blood flow in proliferative retinopathy. Blair et $a^{29}$ found that mean circulation time is normal in noor background retinopathy and prolonged in proliferative retinopathy. Yoshida et al ${ }^{22}$ reported that mean circulation time was significantly increased only in proliferative retinopathy and similar to that of normal persons in no or nonproliferative retinopathy. In a study of Grunwald et al $^{19}$ arterial and venous blood flow was less than normal in background and proliferative retinopathy and similar to that of normal persons in diabetics with no retinopathy. The calculated volumetric blood flow rate, however, did not differ from normal in all stages of retinopathy without retinal photocoagulation. ${ }^{19}$ Rimmer et $a l^{18}$ reported in a long-term follow-up study that the perifoveolar blood velocity (measured by blue light entoptic phenomenon) decreased in the course of diabetic retinopathy.

In our investigation a larger number of a specific subgroup of diabetics (adult juvenileonset insulin dependent) was studied than reported elsewhere. All groups of different stages of diabetic retinopathy showed a prolonged AVP. There was a trend to increasing AVP with progressing diabetic retinopathy.

Dependence of the retinal blood flow on the duration of diabetes mellitus was examined by Oswald et al. ${ }^{16}$ They reported an increase of blood flow velocity, with a maximum among patients with a 10-20 years' history of diabetes mellitus. In contrast, we found a normal AVP in patients with a history of diabetes of less than five years and a worse retinal microcirculation in diabetics with longer duration of the disease.

By means of blue field entopic phenomenon Fallon et $\mathrm{ll}^{30}$ and Davies et $a l^{25}$ showed that acute fluctuations in plasma glucose levels are not associated with changes of perifoveal blood flow. In addition, no difference was found in the response of macular blood flow to hyperoxia (autoregulation) with high and normal blood glucose levels..$^{30}$ Laser Doppler velocimetry ${ }^{19} \mathrm{did}$ not show any correlation between acute blood glucose levels and arterial or venous blood flow velocity in insulin dependent diabetics. In 12 type 2 diabetics Grunwald $e t a l^{31}$ found a decreasing retinal blood flow within three hours after onset of a decrease in blood glucose from hyperglycaemia to normoglycaemia. The study presented here showed AVP of diabetics with good or bad long term diabetic control within the last 4-6 weeks before examination (HbAlc). The diabetics with bad glycaemic control showed a longer AVP than did patients with good glycaemic control. Diabetics without signs of retinopathy (DR 0) and good glycaemic control had a similar AVP as compared with healthy persons. These results may indicate that bad glycaemic control worsens the retinal microcirculation and may lead to a more severe course of diabetic retinopathy. In the proliferative stage the retinal microcirculation was even more disturbed. Only in this group did the AVP seem to be independent of good glycaemic control.

The ART allows for a rough estimation of the macrocirculation. The type 1 diabetics studied here showed similar values of ART to those of healthy adults. Only the patients with history of diabetes $\geqslant 25$ years showed an increased ART (Table 6). This may indicate that only some of the patients with a long history of diabetes participating in this study suffered from disturbed macrocirculation. Disturbed macrocirculation is an unlikely cause of increased AVP because of the normal ART we encountered in most of the diabetics.

In conclusion, the retinal circulation in juvenile-onset insulin dependent adult diabetics is decreased as compared with that of healthy persons. AVP values similar to those of normal persons were found only in diabetics (1) with duration of diabetes of less than five years or (2) without retinopathy and with good glycaemic control. Bad glycaemic control seems to worsen retinal microcirculation. This may be one cause of the increasing prevalence of ischaemic lesions 
and their vascular complications in patients with a long history of diabetes mellitus.

This work was supported by the Deutsche Forschungsgemeinschaft (DFG): Re 152/25-1.

1 Wolf S, Jung F, Kiesewetter H, Körber N, Reim M. Video fluorescein angiography: method and clinical application. Graefes Arch Clin Exp Ophthalmol 1989; 227: 145-51.

2 Wolf S, Toonen H, Koyama T, Meyer-Ebrecht D, Reim M. Scanning laser ophthalmoscopy for the quantification of retinal blood flow parameters: a new imaging technique. In: Nasemann JE, Burk ROW, eds. Scanning laser ophthalmoscopy and tomography. München: Quintessenz, 1990:91-6.

3 Laube $\mathrm{H}$. Hat sich die Bestimmung von $\mathrm{Hb}-\mathrm{Al}$ in der Diabeteskontrolle bewährt? Dtsch med Wochenschr 1985; 110: $823-5$

4 Holm S. A simple sequentially rejective multiple test procedure. Scand 7 Stat 1979; 6: 65-70

5 Apple DJ, Rabb MF. Ocular pathology. St Louis: Mosby, 1985

6 Rimmer T, Fleming J, Kohner EM. Hypoxic viscosity and diabetic retinopathy. Br F Ophthalmol 1990; 74: 400-4.

7 Lowe GD, Ghafour IM, Belch JJF, Forbes CD, Foulds WS, MacCuish AC. Increased blood viscosity in diabetic proliferative retinopathy. Diabetes Res 1986; 3: 67-70.

8 Tillmann W, Lakomek M, Heidemann P, Behrens-Baumann W, Schröter W. Aggregate formation of erythrocytes and diabetic retinopathy in children, adolescents and adults with diabetes mellitus (type I). Klin Wochenschr 1984; 62: 1136-9.

9 Schmid-Schönbein H, Volger E. Red-cell aggregation and redcell deformability in diabetes. Diabetes 1976; 25: 897-902.

10 Othmane A, Bitbol M, Snabre P, Mills P, Grimaldi A, Bosquet $F$. Red-cell aggregation in insulin-dependent diabetics. Clin F. Red-cell aggregation in insul

11 Porta M, Hilgard P, Kohner EM. Platelet shape change abnormalities in diabetic retinopathy. Diabetologia 1980; 18: 217-21.

12 Agardh CD, Agardh E, Bauer B. Platelet aggregation in type I diabetics with and without proliferative retinopathy. Acta Ophthalmol (Kbh) 1987; 65: 358-62.

13 Soeldner JS, Christacopoulos PD, Gleason RE. Mean retinal circulation time as determined by fluorescein angiography in normal prediabetic and chemical-diabetic subjects. Diabetes 1976; 252: 903-8.

14 Kohner EM, Hamilton AM, Saunders SJ, Sutcliffe BA, Bulpitt CI. The retinal blood flow in diabetes. Diabetologia Bulpitt CJ. The reil

15 Cunha-Vaz JG, Fonesca JR, De Abreu JRF. Studies on retinal blood flow: II. Diabetic retinopathy. Arch Ophthalmol 1978; 96: 809 .

16 Oswald B, Vilser W, Oswald H, Jütte A, Königsdorfer E, Schweitzer D. Messung strömungsphysiologischer Grössen der Netzhautzirkulation bei Diabetikern Typ 1 und 2 . Graefes Arch Clin Exp Ophthalmol 1983; 220: 42-6.
17 Fallon TJ, Maxwell DL, Kohner EM. Autoregulation of retinal blood flow in diabetic retinopathy measured by the blue-light entoptic technique. Ophthalmology 1987; 94: $1410-5$.

18 Rimmer T, Fallon TJ, Kohner EM. Long-term follow-up of retinal blood flow in diabetes using the blue light entoptic phenomen Br 7 Ophthalmol 1989; 73: 1-5.

19 Grunwald JE, Riva CR, Sinclair SH, Brucker AJ, Petrig BL. Laser Doppler velocimetry study of retinal circulation in Laser Doppler velocimetry study of retinal circulation

20 Ferrer O. Retinal circulation times. Ophthalmologica 1969; 157: 89-103.

21 Koerner F, Fries K, Niesel P, Dubied P. Zur Interpretation der retinalen Kreislaufzeiten bei der diabetischen Retinopathie vor und nach Photokoagulation. Klin Mbonatsbl Augenheilkd 1978; 172: 440-4.

22 Yoshida A, Feke GT, Morales-Stoppello J, Collas GD, Goger DG, MacMeel JW. Retinal blood flow alterations during progression of diabetic retinopathy. Arch Ophthalmol 1983; progression $225-7$.

23 Reim M, Körber N, Wolf S, Jung F. Quantitative Videoangiographie der Retina bei Patienten mit Diabetes mellitus Typ II. In: Kiesewetter H, Ehrly AM, Jung F, eds. Hämorheologische Messmethoden. 3. Kongress der Deutschen
Gesellschaft für Klinische Hämorheologie e. V. (DGKH). Gesellschaft für Klinische Hämorheologie e. V. (DGKH). München:

24 Bertram B, Wolf S, Elbers M, Joussen W, Reim M. Untersuchung retinaler Kreislaufzeiten bei Patienten mit insulinpflichtigem Diabetes mellitus Typ II. Fortschr Ophthalmol 1988; 85: 413-5.

25 Davies EG, Hyer SL, Kohner EM. Macular blood flow response to acute reduction of plasma glucose in diabetic patients measured by the blue light entoptic technique. Ophthalmology 1990; 97: 160-4.

26 Körber N, Wolf S, Kranemann C, Lück M. Quantitative konjunctivale Videokapillaroskopie in der Diagnostik von Mikrozirkulationsstörungen. Sitzungsbericht der 148. Versammlung des Vereins Rheinisch-Westfälischer Augenärzte 1986: 245-9.

27 Ditzel J, Saglid U. Morphologic and hemodynamic changes in the bulbar conjunctiva of normotensive diabetic patients. N Engl F Med 1954; 250: 587-94.

28 Fagrell B, Hermansson IL, Karlander SG, Ostergren J. Vital capillary microscopy for assessment of skin viability and microangiopathy in patients with diabetes mellitus. Acta Med Scand 1984; 687 (Suppl): 25-8.

29 Blair NP, Feke GT, Morales-Stopello J, et al. Prolongation of the retinal mean circulation time in diabetes. Arch Ophthalthe retinal mean circulat

30 Fallon TJ, Sleightholm MA, Merrick C, Chahal P, Kohner EM. The effect of acute hyperglycemia on flow velocity in the macular capillaries. Invest Ophthalmol Vis Sci 1987; 28: 1027-30.

31 Grunwald JE, Riva CE, Martin DB, et al. Effect of an insulininduced decrease in blood glucose on the human diabetic retinal circulation. Ophthalmology 1987; 94: 1614-20. 